\title{
STUDI KOMPARATIF FRAKSI AIR SUSU IBU PERAH SEGAR DAN BEKU DALAM MENGHAMBAT BAKTERI Enterotoksigenik Escherichia coli
}

\section{Comparative Study of Fresh and Frozen Human Breast Milk against the Growth of Enterotoxigenic Escherichia coli}

\author{
Andita Ayu Mandasari*, Intan Chairun Nisa
}

\author{
Fakultas IImu Kesehatan Universitas Maarif Hasyim Latif \\ Jl. Ngelom Megare No 30, Sepanjang, Sidoarjo, Jawa Timur 61257, Indonesia \\ *Penulis Korespondensi, Email: andita_ayu_mandasari@dosen.umaha.ac.id
}

\begin{abstract}
ABSTRAK
Sumber nutrisi utama untuk pertumbuhan dan proteksi bayi yang mengandung makronutrisi, mikronutrisi, dan senyawa bioaktif adalah air susu ibu (ASI). Kegagalan menyusui dialami lebih banyak oleh ibu yang bekerja. Saat ini, pemberian ASI perah beku merupakan solusi alternatif tetapi kemampuan senyawa imunologis ASI perah beku dalam menghambat bakteri penyebab diare mungkin mengalami penurunan. Tujuan penelitian ini adalah membandingkan dan mengetahui kemampuan fraksi ASI segar dan beku dalam menghambat pertumbuhan bakteri Enterotoksigenik Escherichia coli (ETEC). Penelitian ini menggunakan quasi-experimental design dengan tujuh sampel ASI dengan kondisi empat belas hari pasca melahirkan dan disentrifugasi untuk mendapatkan fraksi supernatan dan pelet. Hasil penelitian ini adalah ada penurunan yang signifikan pada whole milk, supernatan, dan pelet ASI segar maupun beku dalam menghambat pertumbuhan ETEC. Fraksi supernatan pada ASI segar dan beku memiliki kemampuan lebih tinggi dalam menghambat bakteri dibandingkan dengan whole milk dan fraksi pelet.
\end{abstract}

Kata kunci: ASI, Beku, Enterotoxigenic E coli

\section{ABSTRACT}

The source of nutrition containing macronutrients, micronutrients, and essential bioactive compounds that crucial for infant's growth and protection is human breast milk. Breast milk-feeding failure experienced by working mothers. Nowadays, frozen breast milk is a solution for working mothers. However, the ability of immunological compounds in frozen breast milk might decrease the inhabitation of bacteria causing diarrhea. The aim of this study is to compare and know the ability of breast milk fraction between fresh and frozen against Enterotoxigenic Escherichia coli (ETEC) directly. Quasi-experimental design with seven mothers expressed breast milk within maximal fourteen days postpartum. Each sample was centrifuged to obtain supernatant and pellet fraction. The results are there was decreasing ability of frozen whole milk, supernatant, and pellet fraction against bacteria compared to fresh breast milk. Supernatant fractions (fresh and frozen) have higher ability to decrease bacteria compared with whole milk and pellet fraction.

Keywords: Breast milk, Frozen, Enterotoxigenic E coli

\section{PENDAHULUAN}

Sumber nutrisi yang lengkap bagi bayi adalah air susu ibu (ASI). Air susu ibu mengandung makronutrien, mikronutrien, dan senyawa bioaktif yang penting dalam pertumbuhan dan perkembangan bayi (Ballard and Morrow, 2013). Air susu ibu juga dapat mengurangi resiko penyakit seperti otitis media, infeksi saluran pencernaan, bronchiolitis, dan asma (Eidelman, 2012). Selain itu, hasil penelitian menunjukkan bahwa air susu ibu 
memiliki mekanisme imunitas alami yang dapat melindungi bayi dari diare (Santana et al., 2012; Kakulas, 2015). Hal ini dikarenakan ASI mengandung banyak komponen imunologis yang bertanggung jawab dalam memberikan fungsi proteksi kepada bayi seperti sitokin, laktoferin, imunoglobulin A ( $\lg$ A), makrofag dan netrofil (Newburg et al., 2005).

Data yang diperoleh dari United Nations Children's Emergency Fund (UNICEF) menyebutkan bahwa pembunuh utama anak-anak di bawah 5 tahun adalah diare (WHO, 2016). Pada tahun 2015, sebanyak 1400 anak per hari meninggal karena diare. Negara Afrika dan Asia adalah penyumbang kasus kematian karena diare sebesar $78 \%$. Di Indonesia, sekitar 8292 anak meninggal akibat diare pada tahun 2015 (WHO, 2016). Penyebab diare yaitu infeksi bakteri yang masuk bersama dengan makanan atau air. Bakteri tersebut adalah Enterotoksigenik Escherichia coli (ETEC) yang merupakan penyebab terbanyak diare pada bayi (Farthing et al., 2013). Resiko diare pada bayi diharapkan dapat menurun dengan pemberian ASI. Akan tetapi cakupan pemberian eksklusif di Indonesia masih dibawah target nasional sebesar 80\% (BPS, 2012; Depkes, 2003). Beberapa penelitian menyebutkan bahwa kegagalan pemberian ASI eksklusif karena ibu bekerja (Haryani dkk., 2014; Rahmah, 2006). Saat ini pemberian ASI perah (ASIP) beku menjadi solusi alternatif sehingga ibu bekerja masih dapat memberikan ASI eksklusif. Namun, ASIP beku dikhawatirkan dapat mempengaruhi komponen imunologis sehingga menurunkan kemampuan dalam menghambat bakteri patogen penyebab diare. Penyimpanan ASI pada suhu kulkas $4^{\circ} \mathrm{C}$ mengakibatkan penurunan kemampuan dalam menghambat bakteri patogen seperti Staphylococcus aureus, Eschericia coli, dan Klebsiella pneumonia (Lorico, et al., 2012).

Berbagai strategi dilakukan untuk meningkatkan kuantitas dan kualitas serta nutrisi yang didapatkan bayi terutama pada bayi premature untuk mendukung pertumbuhan optimal bayi. Upaya peningkatan kuantitas ASI salah satunya yaitu dengan memodifikasi sumber makanan yang dikonsumsi ibu. Penelitian yang dilakukan oleh Satyaningtyas dan Estiasih (2014) adalah membuat bahan pangan roti tawar berbahan dasar tepung katuk agar dapat merangsang produksi ASI. Selain itu, strategi yang dapat dilakukan untuk meningkatkan kualitas ASI adalah dengan memfraksinasi ASI menjadi foremilk (susu rendah lemak) dan hindmilk (susu tinggi lemak) (Lalari, 2002). Ketika difraksinasi komponen-komponen ASI akan terpisah menghasilkan tiga lapisan yaitu lapisan krim yang mengandung lemak, protein berupa laktoferin, sitokin, komplemen, immunoglobulin A berada pada lapisan supernatan, sel-sel imun seperti netrofil dan makrofag serta sel epitel payudara berada pada lapisan pelet (Palmeira dan Sampaio, 2016).

Beberapa penelitian seperti Chang et al. (2013) dan Lorico \& Perez (2012) telah menunjukkan kemampuan penghambatan bakteri patogen oleh whole milk ASI beku serta perubahan komponen nutrisi ASI. Akan tetapi, informasi mengenai penghambatan bakteri secara langsung pada setiap fraksi komponen ASI yang telah dibekukan belum banyak dilaporkan. Tujuan penelitian ini adalah mengetahui aktivitas langsung penghambatan pertumbuhan bakteri ETEC oleh tiap komponen fraksinasi ASIP segar dan beku yaitu whole milk, supernatan, dan pelet. Penelitian ini diharapkan mampu memberikan informasi ilmiah kepada masyarakat khususnya ibu menyusui tentang aktivitas komponen imunologis ASIP beku terhadap kemampuannya dalam menghambat bakteri ETEC.

\section{BAHAN DAN METODE}

\section{Persiapan sampel ASIP}

Penelitian ini menggunakan quasi experimental design dengan sampel ASI dari tujuh ibu yang sehat dengan kriteria partus normal maksimal 14 hari pasca melahirkan dan tidak menggunakan obat-obatan tertentu pada bulan Juli di Papilio Natural Birth Center (sertifikat kode etik penelitian dengan nomor 87/EC/KEPK/FKUA/2018). Air susu ibu diambil menggunakan pompa ASI manual yang disediakan oleh peneliti dalam keadaan steril. Sampel ASIP dibagi menjadi kelompok segar dan kelompok perlakuan. Kelompok segar adalah sampel ASI perah yang baru diambil, sementara ASIP pada kelompok perlakuan 
disimpan di freezer lemari pendingin dua pintu selama 3 hari. Lama penyimpanan berdasarkan referensi dari ABM Clinical Protocol (Eglash et al., 2017). Masing-masing kelompok perlakuan dibagi lagi menjadi 3 sub kelompok perlakuan, yaitu: whole milk, supernatan, dan pelet sel.

\section{Preparasi Isolat Bakteri ETEC}

Strain bakteri ETEC diperoleh dari Laboratorium Bakteriologi Fakultas IImu Kesehatan Universitas Maarif Hasyim Latif Sidoarjo. Bakteri tersebut dikultivasi pada nutrient agar selama 24 jam, kemudian koloni bakteri yang terbentuk diambil menggunakan ose dan dimasukkan ke buffered peptone water. Konsentrasi bakteri yang digunakan adalah $1,0 \times 10^{8} \mathrm{CFU} / \mathrm{ml}$ dengan menggunakan standar Mc Farland 0.5.

\section{Prosedur Penghambatan Bakteri ETEC oleh ASIP}

Sampel ASIP disentrifugasi selama 30 menit $\left(200 \mathrm{xg}, 25^{\circ} \mathrm{C}\right)$ untuk mendapatkan fraksi supernatan dan pelet sel. Proses sentrifugasi akan memisahkan tiga fraksi berbeda yaitu: cream layer, supernatan, dan pelet sel. Lapisan atas yaitu cream layer dibuang. Pelet sel dicuci menggunakan phosphate buffer saline (PBS) 1x sebanyak dua kali kemudian ditambahkan medium Roswell Park Memorial Institute (RPMI) dengan penambahan 10\% fetal bovine serum sebanyak $1 \mathrm{ml}$. Sebanyak $1 \mathrm{ml}$ setiap fraksi ditambahkan $0,02 \mathrm{ml}$ bakteri (stok dengan standar Mc Farland 0.5) untuk membuat konsentrasi bakteri $2 \times 10^{5} \mathrm{CFU} / \mathrm{ml}$. Kelompok whole milk dan supernatan diinkubasi di inkubator $37^{\circ} \mathrm{C}$ selama 1 jam, sementara suspensi pelet diinkubasi di inkubator $\mathrm{CO}_{2}$ dengan suhu dan waktu yang sama. Kontrol negatif menggunakan PBS 1x dan ASIP untuk melihat tidak adanya bakteri di dalam ASIP. Setelah inkubasi, suspensi didilusi sebanyak lima kali kemudian dispread pada medium agar selektif Mc Conkay. Inkubasi di dalam inkubator $37^{\circ} \mathrm{C}$ selama 24 jam. Perhitungan koloni bakteri dihitung pada plate agar Mc Conkay dan dipilih pengenceran yang terdapat 30-300 koloni bakteri. Jumlah koloni bakteri yang bertahan hidup menunjukkan kemampuan ASIP dalam menghambat bakteri. Semakin banyak jumlah koloni yang tumbuh maka kemampuan ASIP dalam menghambat bakteri semakin rendah. Sementara itu, sisa suspensi kelompok pelet sel disentrifugasi $\left(200 \mathrm{xg}, 25^{\circ} \mathrm{C}\right)$ selama 10 menit. Sebanyak $10 \mu \mathrm{l}$ medium RPMI digunakan untuk meresuspensi pelet. Selanjutnya dibuat apusan pada gelas objek dan dicat menggunakan Giemsa untuk konfirmasi adanya fagositosis bakteri ETEC oleh makrofag yang berada di dalam pelet sel ASIP.

\section{Analisis Data}

Perbandingan jumlah koloni bakteri yang tumbuh pada masing-masing sub kelompok perlakuan ASIP segar dan beku dianalisis menggunakan Paired-t test dengan nilai kepercayaan 95\%. Uji statistik ANOVA-One Way digunakan untuk membandingkan nilai rata-rata koloni bakteri yang tumbuh pada tiga kelompok sub perlakuan, yaitu: whole milk, supernatan, dan pelet. Pada kelompok ASIP segar, data tidak normal dan homogen sehingga dilanjutkan menggunakan Post Hoc Games Howell $(\alpha=0.05)$. Pada kelompok ASIP beku data yang diperoleh telah homogen sehingga dilanjutkan Post Hoc Test yaitu Bonferroni Test $(\alpha=0.05)$.

\section{HASIL DAN PEMBAHASAN}

Rata-rata koloni bakteri ETEC yang bertahan hidup pada agar selektif Mc Conkay setelah diinkubasi menggunakan fraksi ASIP segar dan beku dijelaskan pada Tabel 1. Prosentase penurunan kemampuan ASIP beku dibandingkan dengan ASIP segar yaitu $50 \%$ pada whole milk, $22 \%$ pada fraksi supernatan, dan $59 \%$ pada fraksi pelet sel. 
Tabel 1. Rata-Rata Koloni Bakteri ETEC Yang Dapat Bertahan Hidup Setelah Penambahan Fraksi ASIP Segar Dan Beku

\begin{tabular}{|c|c|c|c|c|c|c|c|}
\hline \multirow{2}{*}{ Sampel } & \multicolumn{2}{|c|}{ Whole milk (CFU/ml) } & \multicolumn{2}{|c|}{$\begin{array}{l}\text { Supernatan } \\
\text { (CFU/mI) }\end{array}$} & \multicolumn{3}{|c|}{ Pelet (CFU/ml) } \\
\hline & $\begin{array}{l}\text { ASIP } \\
\text { Segar }\end{array}$ & $\begin{array}{l}\text { ASIP } \\
\text { Beku }\end{array}$ & $\begin{array}{l}\text { ASIP } \\
\text { Segar }\end{array}$ & $\begin{array}{l}\text { ASIP } \\
\text { Beku }\end{array}$ & $\begin{array}{l}\text { ASIP } \\
\text { Segar }\end{array}$ & & $\begin{array}{l}\text { ASIP } \\
\text { Beku }\end{array}$ \\
\hline$A$ & 1160 & 2480 & 760 & 793 & 3216.67 & & 8233 \\
\hline B & 1427 & 2113 & 550 & 867 & 4700 & & 7633 \\
\hline C & 1683 & 2603 & 897 & 900 & 3207 & & 8767 \\
\hline D & 1320 & 2907 & 803 & 970 & 3223 & & 7700 \\
\hline $\mathrm{E}$ & 1880 & 4567 & 643 & 1213 & 4400 & & 11067 \\
\hline $\mathrm{F}$ & 1470 & 3293.33 & 613.33 & 956.67 & 3020 & & 7666.67 \\
\hline G & 1453.33 & 2773 & 796.67 & 813 & 2923.33 & & 8933 \\
\hline Rata-rata & $\begin{array}{l}1484.76 \\
235.47\end{array}$ & $\pm \begin{array}{l}2962.33 \\
796.51^{*}\end{array}$ & $\begin{array}{l}723.29 \pm \\
123.71^{a}\end{array}$ & $\begin{array}{l}930.38 \pm \pm \\
141.26^{* * \mathrm{~b}}\end{array}$ & $\begin{array}{l}3527.14 \\
713.05\end{array}$ & \pm & $\begin{array}{l}8571.38 \pm \\
1222.70^{\star *}\end{array}$ \\
\hline $\begin{array}{l}\text { Prosentase } \\
\text { penurunan (\%) }\end{array}$ & \multicolumn{2}{|r|}{50} & \multicolumn{2}{|c|}{22} & \multicolumn{3}{|c|}{59} \\
\hline
\end{tabular}

Tabel 1 menunjukkan nilai rata-rata bakteri ETEC yang tumbuh pada medium setelah inkubasi. Uji statistik menunjukkan ada penurunan yang signifikan antara kemampuan whole milk, supernatan, dan pelet ASIP beku dibandingkan dengan ASIP segar dalam menghambat bakteri ETEC $\left({ }^{*} p=0.001\right.$ [whole milk ASIP segar dengan whole milk ASIP beku]; ${ }^{* *} p=0.042$ [supernatan ASIP segar dengan supernatan ASIP beku]; ${ }^{* *} p=0.000$ [pelet ASIP segar dengan pelet ASIP beku] ). Selain itu, kemampuan fraksi supernatan baik ASIP segar maupun beku lebih tinggi dalam menghambat pertumbuhan bakteri ETEC dibandingkan dengan fraksi pelet dan whole milk (a,b $p<0.05)$.

Gambar 1 menunjukkan proses fagositosis bakteri ETEC di dalam ASI. Pada gambar tersebut nampak bakteri ETEC (panah kuning) di dalam sel makrofag (panah merah). Hal ini membuktikan bahwa salah satu sel imun di dalam ASI yaitu makrofag ASI masih memiliki kemampuan dalam melakukan fagositosis meskipun terjadi penurunan kemampuan yang signifikan pada ASIP beku dibandingkan dengan ASIP segar.

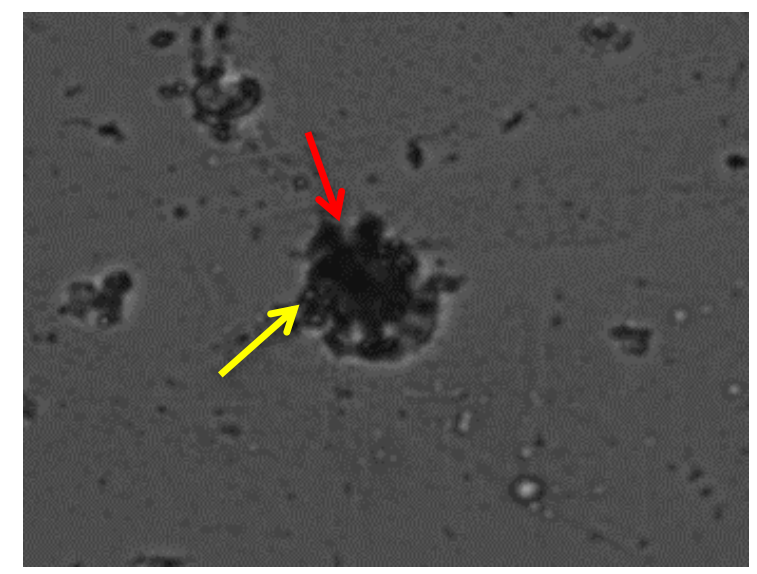

Gambar 1. Konfirmasi Proses Fagositosis Makrofag Pada Pelet Sel ASIP Beku Terhadap Bakteri ETEC (Giemsa, 400x).

Proses sentrifugasi ASIP akan memisahkan ASI menjadi 3 fraksi yaitu: cream layer yang berisi lemak, supernatan yang berisi protein dan komponen imunologis seperti lactoferin, secretory imunoglobulin A (slgA), cathelicidine, defensin, serta pelet sel yang berisi sel-sel imun seperti makrofag, netrofil, dan limfosit (Palmeira dan Sampaio, 2016). Proses penyimpanan pada freezer lemari es dapat menurunkan kemampuan ASI dalam menghambat bakteri patogen. 
Menurut penelitian yang dilakukan oleh Santana et al. (2012) konsentrasi slg A dan IL-6 pada ASIP yang disimpan di dalam freezer selama enam bulan tidak mengalami perubahan, sedangkan laktoferin mengalami penurunan tetapi tidak signifikan (Chang et al., 2013). Interleukin-6 adalah sitokin pada ASI yang dapat menginduksi class switching IgA dan mengatur pertahanan sistem imun mukosa (Newburg et al., 2005). Meskipun beberapa penelitian menunjukkan protein yang berfungsi dalam proteksi tubuh tidak mengalami perubahan yang berbeda nyata akan tetapi hasil penelitian menunjukkan bahwa whole milk, fraksi supernatan dan fraksi pelet ASIP beku mengalami penurunan yang signifikan dibandingkan dengan ASIP segar dalam menghambat bakteri ETEC (Tabel 1). Pada fraksi supernatan, kemampuan dalam menghambat bakteri ETEC mengalami penurunan yang signifikan sebesar $22 \% \mathrm{Hal}$ ini diakibatkan oleh penurunan konsentrasi dan aktivitas lisozim pada ASIP beku (Chang et al., 2013). Lisozim merupakan suatu enzim yang dapat menghancurkan dinding bakteri gram positif dan gram negatif (Golinelli et al., 2014). Beberapa penelitian terhadap enzim menunjukkan bahwa proses freezing dapat menyebabkan protein kehilangan sebagian struktur tersier, agregasi protein, destabilisasi struktur sehingga kehilangan fungsi katalitik, serta denaturasi protein (Bortolin et al., 2017; Gabellieri dan Strambini, 2003; Franks, 1995)

Fraksi pelet pada ASIP mengandung banyak sel imun yaitu makrofag, netrofil dan limfosit (Patki et al., 2014). Makrofag adalah leukosit dengan jumlah paling banyak sebesar $40-50 \%$ dari total leukosit pada kolostrum ASI diikuti oleh neutrophil (40-50\%), sedangkan limfosit sekitar $5-10 \%$ dari total leukosit (Hassiotou et al, 2013a). Jumlah ini akan menurun pada ASI transisional ( $7-14$ hari post partum) dan matur (26 - 30 hari post partum) sebesar $0-1,7 \%$ dan $0-1,5 \%$ (Hassiotou et al, 2013 ${ }^{\mathrm{b}}$ ). Data tersebut mendukung sampel ASIP yang digunakan dalam penelitian ini didapat dari ibu dengan post partum maksimal 14 hari. Penurunan jumlah leukosit pada ASIP akan mempengaruhi konsentrasi lisozim yang merupakan hasil produksi dari leukosit termasuk makrofag (Flannagan et al., 2015). Makrofag dan netrofil dilaporkan mengalami penurunan jumlah yang signifikan pada ASIP yang disimpan di dalam freezer pada suhu $0-4^{\circ} \mathrm{C}$ selama 48 jam (Lawrence, 1999). Selain itu, menurut Kakulas (2015) sel-sel imun tidak mampu bertahan hidup setelah proses freezing atau pasteurisasi yang memperkuat hasil penelitian yaitu kemampuan fraksi pelet ASIP beku dalam menghambat bakteri ETEC mengalami penurunan yang signifikan yaitu sebesar 59\% dibanding dengan ASIP segar. Proses freezing dan thawing akan mengakibatkan sel mengalami peningkatan permeabilitas akibat dari kerusakan integritas pada membran sel (Perumal, 2014).

Perbandingan kemampuan fraksi ASIP segar dan beku dalam menghambat bakteri ETEC menunjukkan bahwa fraksi supernatan lebih baik dalam menghambat bakteri ETEC dibandingkan whole milk dan pelet (Tabel 1). Hal ini dikarenakan di dalam supernatan terdapat banyak protein yang berfungsi sebagai antimikrobial yaitu laktoferin, secretory $\lg A$, sitokin, lisozim, kasein, dan alfa-Laktabulmin (Haschke et al., 2016). Sel imun yaitu makrofag dan netrofil di dalam pelet ASIP baik segar maupun beku memiliki kemampuan lebih rendah dalam menghambat bakteri ETEC dibandingkan dengan whole milk dan fraksi supernatan. Makrofag dan netrofil adalah sel imun yang berperan dalam proses fagositosis patogen. Kedua sel tersebut dapat melakukan fagositosis secara independen, akan tetapi dalam sistem imun, makrofag dan netrofil akan lebih kuat jika dapat melakukan opsonisasi dengan antibodi. Hal ini diperkuat dengan adanya penelitian yang dilakukan oleh Thorpe et al., (1986) yang menunjukkan mekanisme opsonisasi makrofag dengan slgA ASI pada usus bayi. Selain itu, sitokin tidak dapat melakukan peran autokrin atau parakrin karena sel mungkin kehilangan fungsinya akibat proses freezing dan thawing. Sitokin merupakan peptida yang berperan dalam komunikasi antar sel untuk memberi sinyal aktivitas imun (Ballard dan Morrow, 2013).

Meskipun hasil penelitian menunjukkan adanya penurunan yang signifikan pada fraksi ASIP beku dibandingkan dengan ASIP segar akan tetapi ASIP beku masih mampu melawan bakteri ETEC jika dibandingkan dengan jumlah kontrol bakteri yang digunakan pada penelitian ini. 


\section{SIMPULAN}

Berdasarkan hasil penelitian maka dapat disimpulkan bahwa kemampuan ASIP beku baik whole milk, fraksi supernatan maupun fraksi pelet mengalami penurunan yang signifikan dalam menghambat bakteri ETEC dibandingkan dengan ASIP segar. Selain itu, fraksi supernatan ASIP beku maupun ASIP segar memiliki kemampuan lebih tinggi dalam menghambat bakteri ETEC dibandingkan whole milk dan fraksi pelet.

\section{UCAPAN TERIMA KASIH}

Ucapan terima kasih penulis sampaikan kepada Papilio Natural Birth Center Sidoarjo yang telah membantu peneliti dalam menyediakan sampel ASI dan kepada Kemenristekdikti yang memberikan dukungan dana hibah Penelitian Dosen Pemula (PDP) tahun anggaran 2018.

\section{DAFTAR PUSTAKA}

Badan Pusat Statistik (BPS). 2012. Survei Demografi dan Kesehatan Indonesia (SDKI) Laporan Pendahuluan. Kerjasama BPS, BKKBN dan Kementerian Kesehatan. Measure DHS ICF International. Jakarta.

Ballard, O. and Morrow, A.L., 2013. Human milk composition: nutrients and bioactive factors. Pediatric Clinics 60:1, pp.49-74.

Bortolin, R.C., Gasparotto, J., Vargas, A.R., da Silva Morrone, M., Kunzler, A., Henkin, B.S., Chaves, P.R., Roncato, S., Gelain, D.P. and Moreira, J.C.F., 2017. Effects of FreezeThaw and Storage on Enzymatic Activities, Protein Oxidative Damage, and Immunocontent of the Blood, Liver, and Brain of Rats. Biopreservation and biobanking, 15(3), pp.182-190.

Chang, J.C., Chen, C.H., Fang, L.J., Tsai, C.R., Chang, Y.C. and Wang, T.M., 2013. Influence of prolonged storage process, pasteurization, and heat treatment on biologically-active human milk proteins. Pediatrics \& Neonatology 54:6, pp.360-366.

Depkes R.I. 2003. Indikator Indonesia sehat 2010 dan pedoman penetapan indikator provinsi sehat Kepmenkes nomor: 1202/Menkes/SK/VIII/2003. Jakarta.

Eglash, A., Simon, L. and Academy of Breastfeeding Medicine, 2017. ABM clinical protocol\# 8: human milk storage information for home use for full-term infants, Revised 2017. Breastfeeding Medicine 12:7, pp.390-395.

Eidelman, A.I., 2012. Breastfeeding and the use of human milk: an analysis of the American Academy of Pediatrics 2012 Breastfeeding Policy Statement. Breastfeeding medicine, 7:5, pp.323-324.

Farthing, M., Salam, M.A., Lindberg, G., Dite, P., Khalif, I., Salazar-Lindo, E., Ramakrishna, B.S., Goh, K.L., Thomson, A., Khan, A.G. and Krabshuis, J., 2013. Acute diarrhea in adults and children: a global perspective. Journal of clinical gastroenterology 47:1, pp.12-20.

Flannagan, R.S., Heit, B. and Heinrichs, D.E., 2015. Antimicrobial mechanisms of macrophages and the immune evasion strategies of Staphylococcus aureus. Pathogens, 4(4), pp.826-868.

Franks, F., 1995. Protein destabilization at low temperatures. In Advances in protein chemistry (Vol. 46, pp. 105-139). Academic Press.

Gabellieri, E. and Strambini, G.B., 2003. Perturbation of protein tertiary structure in frozen solutions revealed by 1-anilino-8-naphthalene sulfonate fluorescence. Biophysical journal, 85(5), pp.3214-3220. 
Golinelli, L.P., Del Aguila, E.M., Flosi Paschoalin, V.M., Silva, J.T. and Conte-Junior, C.A., 2014. Functional aspect of colostrum and whey proteins in human milk. J Hum Nutr Food Sci, 2:3, p.1035.

Haryani, H., Wulandari, L.P.L. and Karmaya, I.N.M., 2014. Alasan Tidak Diberikan ASI Eksklusif oleh Ibu Bekerja di Kota Mataram Nusa Tenggara Barat. Public Health and Preventive Medicine Archive, 2(2), hal. 162-168

Haschke, F., Haiden, N. and Thakkar, S.K., 2016. Nutritive and bioactive proteins in breastmilk. Annals of Nutrition and Metabolism 69:Suppl. 2, pp.16-26.

Hassiotou, F., Geddes, D.T. and Hartmann, P.E., 2013ª. Cells in human milk: state of the science. Journal of Human Lactation 29:2, pp.171-182.

Hassiotou, F., Hepworth, A.R., Metzger, P., Tat Lai, C., Trengove, N., Hartmann, P.E. and Filgueira, L., 2013 . Maternal and infant infections stimulate a rapid leukocyte response in breastmilk. Clinical \& translational immunology 2:4, p.e3.

Kakulas, F., 2015. Breast milk: a source of stem cells and protective cells for the infant. Infant 11:6, pp.187-191.

Lalari, Vikki Valjeet. 2002. Fractionation of expressed milk for the selective collection of hindmilk by mothers who deliver premature infants. PhD diss., University of British Columbia. Available

from https://open.library.ubc.ca/clRcle/collections/ubctheses/831/items/1.0090813

Lawrence, R.A., 1999. Storage of human milk and the influence of procedures on immunological components of human milk. Acta Paediatrica, 88, pp.14-18.

Lorico, J.L.L., and Perez, M. 2012. Effects of storage process on the bacterial growthinhibiting activity of expressed human breast milk on common neonatal pathogens, Staphylococcus aureus, Escherichia coli and Klebsiella pneumoniae." Pediatric Infectious Disease Society of the Philippines Journal 13, no. 1: 2-7. Available from http://www.pidsphil.org/pdf/Journal_01012012/j042_ja01.pdf

Newburg, D.S., Ruiz-Palacios, G.M. and Morrow, A.L., 2005. Human milk glycans protect infants against enteric pathogens. Annu. Rev. Nutr. 25, pp.37-58.

Palmeira, P. and Carneiro-Sampaio, M., 2016. Immunology of breast milk. Revista da Associação Médica Brasileira 62:6, pp.584-593.

Patki, S. M., V. T. Mali, U. S. Patki, and S. S. Patki. 2014. Cytology of the Human Milk in the First Post Partum Week-A Clinical Perspective. J Cytol Histol S 4: 2. Available from: https://www.omicsonline.org/open-access/cytology-of-the-human-milk-in-the-firstpost-partum-week-a-clinical-perspective-2157-7099.S4-009.php?aid=35474 DOI: 10.4172/2157-7099.S4009

Perumal, P., 2014. Effect of superoxide dismutase on semen parameters and antioxidant enzyme activities of liquid stored (5 C) Mithun (Bos frontalis) semen. Journal of Animals, 2014.

Rahmah, L., 2006. Atribusi Tentang Kegagalan Pemberian Asi Pada Ibu Pekerja (Sebuah Studi Fenomenologi). Proyeksi, 6(1), hal. 62-70

Santana, R., C., Pérez-Cano, F.J., Audí, C., Castell, M., Moretones, M.G., López-Sabater, M.C., Castellote, C. and Franch, A., 2012. Effects of cooling and freezing storage on the stability of bioactive factors in human colostrum. Journal of dairy science 95:5, pp.2319-2325.

Satyaningtyas, E. dan Teti E. 2014. Roti tawar laktogenik, perangsang ASI, berbasis kearifan lokal daun katuk (Sauropus androgynus (L.) Merr). Jurnal Pangan dan Agroindustri 2:1, p. 121-131.

Thorpe, L.W., Rudloff, H.E., Powell, L.C. and Goldman, A.S., 1986. Decreased response of human milk leukocytes to chemoattractant peptides. Pediatric research 20:4, p.373.

World Health Organization [Internet]. 2016. Geneva: WHO. "Maternal and Child Epidemiology Estimation Group (MCEE) estimates 2015" [Updated Apr 2016; cited 
Studi Komparatif Fraksi Air Susu Ibu Perah Segar dan Beku - Mandasari, dkk Jurnal Pangan dan Agroindustri Vol.7 No.3: 1-8, Juli 2019

2017 June 20]. Available from: https://data.unicef.org/wpcontent/uploads/2015/12/CoD_Diarrhoea_Dec-2015_WHO_MCEE_234.xIsx 